\title{
Epidemiology of Asthma Mortality in Cuba and its Relation to Climate, 1989 to 2003
}

\author{
Silvia Josefina Venero Fernández, MD, Francisco Javier González Barcala, MD, DrSc, Ramón Suárez Medina, MD, \\ Dania Fabré Ortíz, MD, MS, Héctor Manuel Fernández Núñez, PhD
}

\begin{abstract}
Introduction Asthma affects some 300 million people worldwide and causes over 250,000 deaths each year. It is considered a global health problem due to associated high morbidity and mortality rates; disability in inadequately treated patients; years of potential life lost (YPLL); social costs; and impact on the lives of patients, their families and society. Environmental factors, including climatic conditions, are triggers. The 2004 Cuban National Survey on Asthma found a national prevalence of $13 \%(\mathrm{Cl}$ 9.3-16.8).

Objective Describe the relationship between climatic factors and asthma mortality in Cuba from 1989 to 2003.

Methods Data on deaths from asthma in Cuba were obtained from medical death certificates. Crude and adjusted mortality rates were calculated using the 1981 Cuban population as the standard population; the two-parameter exponential smoothing method was used for trend and prediction analyses, with $95 \%$ confidence intervals $(\mathrm{Cl})$ for estimating mortality rates by age, sex and YPLL. ArcView software version 3.3 was used to obtain, adjust, and represent models of meteorological variables, and a bioclimatic atlas was included.
\end{abstract}

Results Asthma mortality rates increased in Cuba in the early 90s and then decreased and stabilized in recent years; a rate of 2 per 100,000 population was predicted for 2008 . For the period under study, $61 \%$ of asthma-related deaths occurred in Cuba's dry winter months (November-April). The meteorological variables related to risk of asthma mortality were: atmospheric pressure (997.7-1024.3 hPa), temperature (21.3-24.3oC), number of rainy days in the dry season (15.5-45.2 days), and cloudiness (2.99-5.51\%). The provinces with the highest risk of asthma mortality were: Havana City, Havana, Ciego de Ávila, and Camagüey.

Conclusions In Cuba, unfavorable weather conditions in some geographic areas can cause the death of asthmatic patients, although these are not the only factors determining asthma mortality. The asthma mortality rate is not alarmingly high and is expected to remain stable. Nevertheless, preventive measures must be maintained, particularly for women, who suffer excess mortality from the disease. Implementation of prevention strategies that take into consideration the seasonal nature of asthma mortality is recommended.

Keywords: Epidemiology, asthma, mortality, climate, asthma in women, respiratory tract diseases, bronchial diseases

\section{INTRODUCTION}

Asthma is a multifactorial chronic inflammatory respiratory illness characterized by bronchial hyper-reactivity to a variety of stimuli. It affects approximately 300 million people worldwide and causes over 250,000 deaths annually, according to the Global Initiative for Asthma (GINA).[1] It is considered a global health problem due to associated morbidity and mortality rates; disability in inadequately treated patients; years of potential life lost (YPLL); related social costs; and impact on the lives of patients, their families, and society.[1-4]

In Cuba, asthma is considered a common illness, according to various nationwide studies.[5 10] In 1981, prevalence was $8.5 \%$ in urban areas and $7.5 \%$ in rural areas; rates in coastal areas were higher than the national average, whereas lower rates were found in mountainous areas,[11] indicating close association between climatic/environmental conditions and asthma. The 2nd National Survey of Risk Factors for Chronic Diseases (2001) found an asthma rate of $15 \%(\mathrm{Cl} 14.5-15.6)$ in the urban population aged >15 years.[12] The 2004 National Survey on Asthma revealed a national prevalence of $13 \%(\mathrm{Cl}$ 9.3-16.8) with no differences between rural and urban areas.[13]

Environmental factors, including climatic conditions, are considered significant triggers for asthma.[11,14] The international literature points to the prominent role of seasonal climate changes in the onset of acute asthma attacks, $[15,16]$ proving fatal in some cases.[17] Several examples from Cuba illustrate this relationship.[5-10] A 2003 study in Camagüey Province reported a close link between seasonal climate changes and increased severity of the illness in $82.08 \%$ of asthma patients.[9] In a 2001 study in Havana City, Molina et al. found a strong correlation between weather conditions typical of the Cuban dry season (lower atmospheric pressure and lower temperatures) and an increase in acute asthma attacks in both children and adults (0.504 and 0.558 , respectively).[10]

Asthma mortality has been studied in Cuba since 1945.[18] Between 1945 and 1949, the rates were 1 per 100,000 population; in the 50s and $60 \mathrm{~s}$, rates oscillated between 2.4 and 2.7 per 100,000 population, reaching 4 per 100,000 in 1974 . For most of the 80 s, asthma mortality was 3 per 100,000 , but that decade ended with a rate of 4 per 100,000, increasing to 6 per 100,000 population by 1993 . [19] This pattern of asthma mortality affects highly productive age groups, especially women, who suffer excess mortality from the disease. Mortality in the 15-24 age group declined during the 90s.[20]

Despite advances in understanding the causes and development of asthma, as well as the availability of modern, effective drug treatments, asthma mortality remains high in many countries.[1] Cuba has been no exception. Recognizing the need for a complex multidisciplinary approach to the physiopathology, diagnosis and treatment of asthma, and considering the morbidity and mortality associated with the disease, the Cuban National Program for Asthma was launched in 1972. More recently, under the general guidelines of Cuba's health strategies, this Program has been updated to recognize the neighborhood family physician and nurse as the cornerstone of health promotion, disease prevention, treatment, and 
Figure 1: Asthma Mortality Patterns, Trends and Predictions. Cuba, 1989-2008

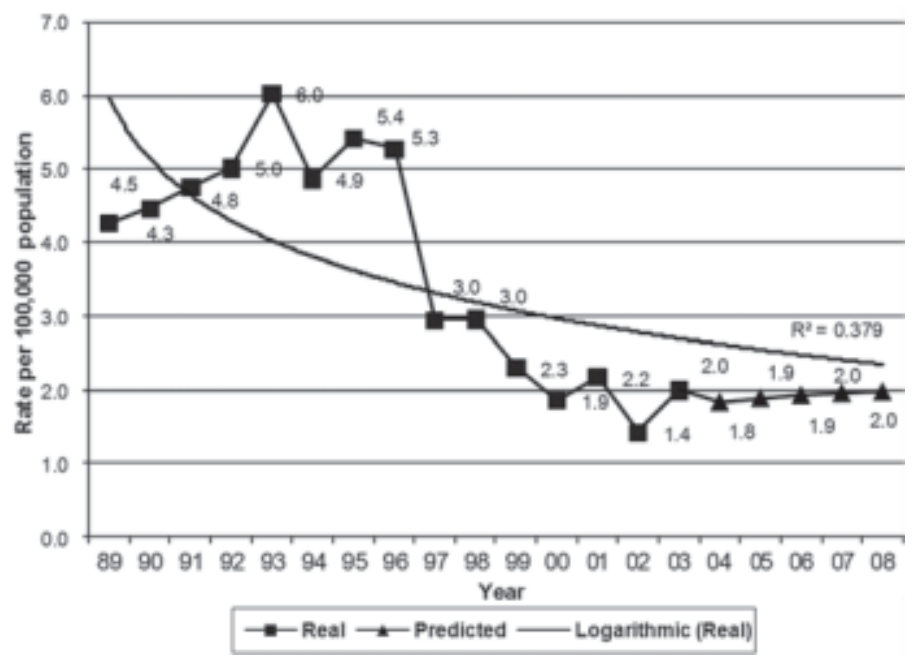

rehabilitation for asthmatic patients. The main goal of the Program is to improve quality of life for these patients and those at risk, and to reduce asthma-related mortality.[21] Implementation of the national Program has contributed to achieving mortality rates similar to those of developed countries today.[1]

At the end of 2006, chronic lower respiratory diseases were the sixth cause of death in Cuba (27.5 per 100,000 population),[22] with asthma accounting for $7.5 \%$ of this total. The asthma mortality rate was 2 per 100,000 population - a considerable drop from

Figure 2: Smoothed Standardized Asthma Mortality Ratio by Municipality. Cuba, 1989-2003

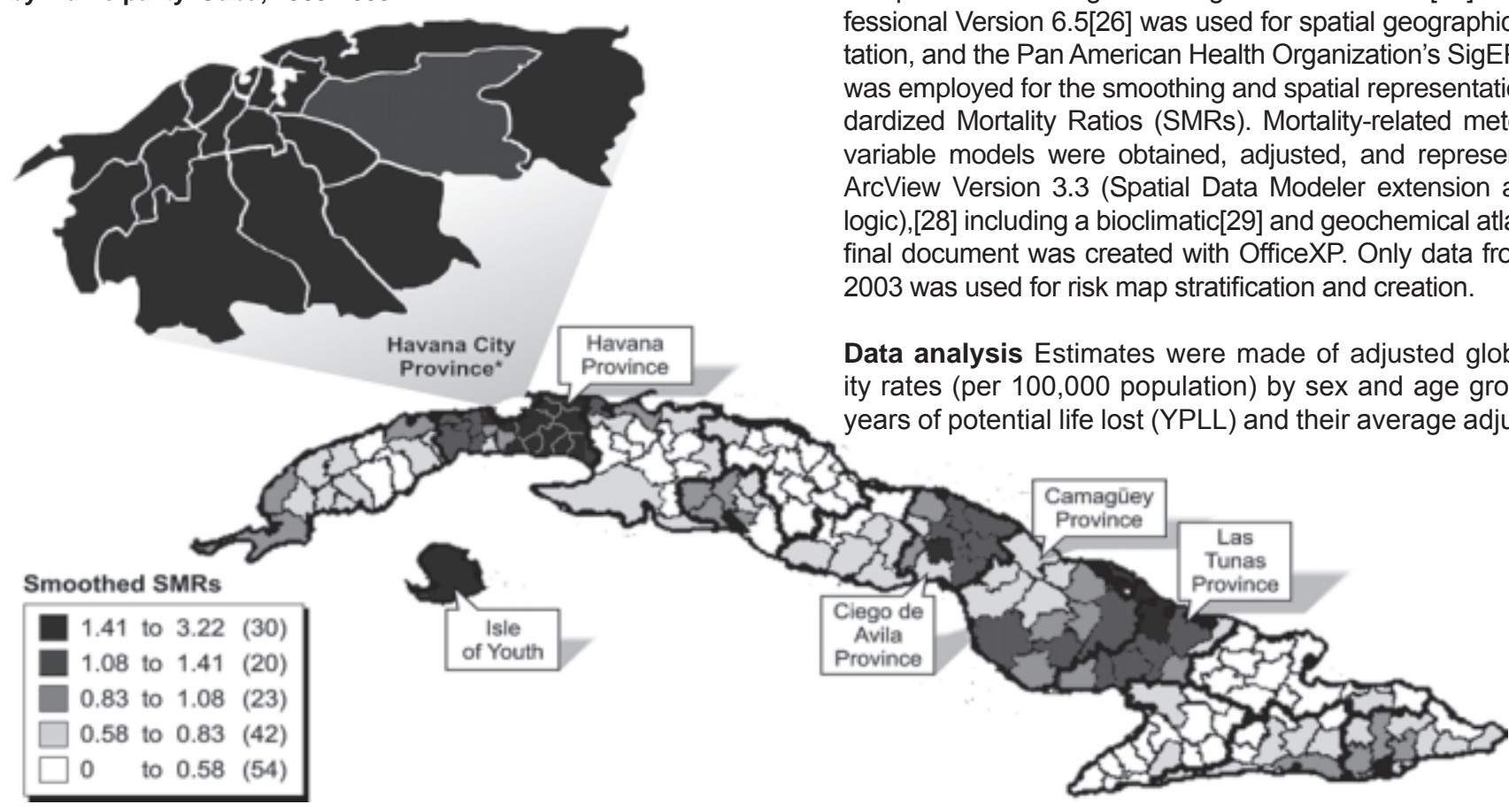

previous years. Despite this decline, the Cuban Ministry of Public Health and healthcare professionals remain concerned about asthma-related deaths and associated risk factors, prompting this study of the relationship between climate factors and the epidemiological behavior of asthma mortality from 1989 to 2003.

\section{METHODS \\ Design This was a mixed ecological study.}

\section{Variables}

Dry season in Cuba: November-April, mean temperature $22^{\circ} \mathrm{C}$. (Compared to $29^{\circ} \mathrm{C}$ during the rainy season, May-October.)

Mortality risk: According to the Smoothed Standardized Mortality Ratio (SSMR), the following categories were established:

- High: $>0.83$

- Mean: 0.58-0.83

- Low: $<0.58$

Meteorological variables: Relative humidity (\%), cloudiness (tenths of sky covered by clouds), atmospheric pressure ( $\mathrm{hPa}$ ), temperature $\left({ }^{\circ} \mathrm{C}\right)$, wind speed $(\mathrm{m} / \mathrm{s})$, rainfall $(\mathrm{mm})$ and bioclimatic index (oxygen density in air).

Information sources Mortality data was obtained from the Ministry of Public Health's National Statistics Division databases. Population data was provided by the National Statistics Office,[23] and meteorological information was provided by the Cuban Meteorology Institute.[24]

Data processing Mortality and population databases were made compatible with the software used in the study, and were managed and processed throughout using SAS version 6.2.[25] MapInfo Professional Version 6.5[26] was used for spatial geographic representation, and the Pan American Health Organization's SigEPI pack[27] was employed for the smoothing and spatial representation of Standardized Mortality Ratios (SMRs). Mortality-related meteorological variable models were obtained, adjusted, and represented using ArcView Version 3.3 (Spatial Data Modeler extension and diffuse logic),[28] including a bioclimatic[29] and geochemical atlas.[30] The final document was created with OfficeXP. Only data from 1999 to Data analysis Estimates were made of adjusted global mortality rates (per 100,000 population) by sex and age group; and of years of potential life lost (YPLL) and their average adjusted rates

(Number of municipalities is given in parentheses)

*Of Havana City Province's 15 municipalities, 14 showed smoothed SMR of 1.41 or higher; only 1 was in the 1.08-1.41 range. 
by period, year, and sex (life expectancy set at 74 years). A two-parameter exponential smoothing method[31] was used to obtain predictions for the 20042008 period. SMRs for the 1989-2003 period were also calculated by municipality and subsequently smoothed using the James-Stein Bayesian estimator in SigEPI,[27] and later processed with the ArcView diffuse logic module[28] to identify risk

\section{Weather Variables} Atmospheric pressure Yearly mean temperature Rainy days during dry season Cloudiness
Figure 3: Asthma Mortality Risk Areas, by Weather Variables. Cuba, 1999-2003

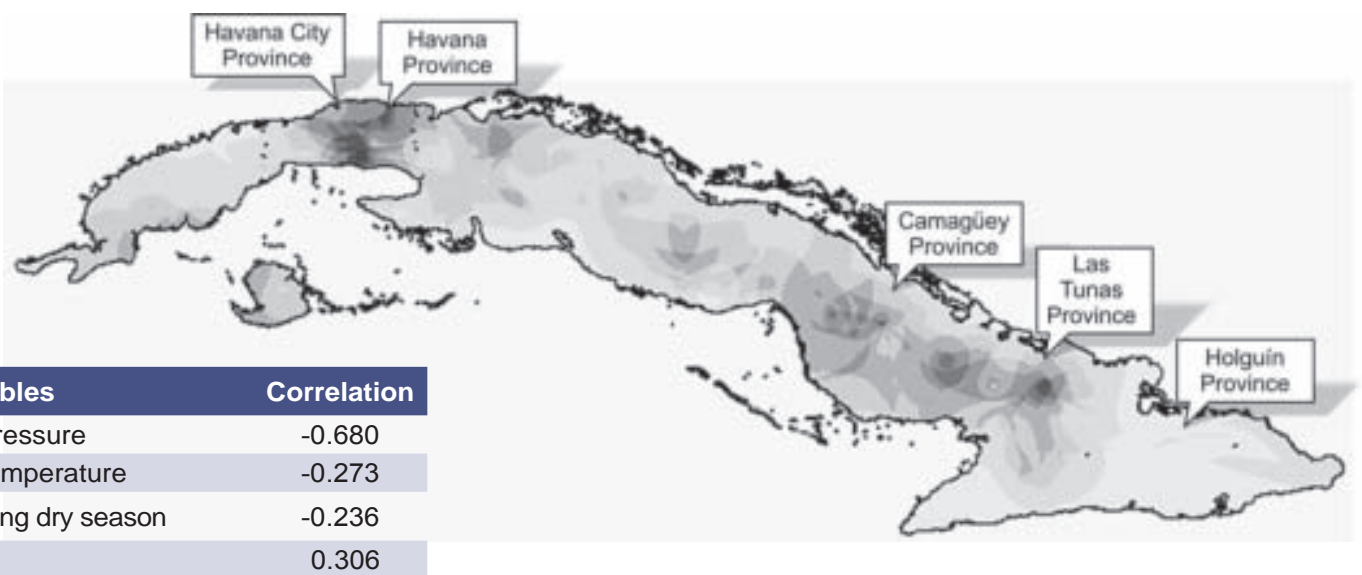
zones (for the 1999-2003 period), taking into account meteorological variables by municipality and choosing the meteorological variables that significantly correlated with the smoothed SMR.

\section{RESULTS}

\section{Asthma mortality behavior, trends and prediction}

Between 1989 and 2003 (Fig. 1), 5,114 asthma-related deaths were reported nationwide, representing $0.3 \%$ of all fatalities. Asthma mortality reached its peak in the early 90 s (6 deaths per 100,000 population) and began a gradual decline until 2003 (2 deaths per 100,000 population), remaining stable at this rate. The same mortality rate (2 per 100,000 population) was predicted for 2008.

\section{Asthma mortality by age group and sex}

Age $\mathbf{0 - 4}$ years: 45 deaths and very low mortality rates $(0.41$ per 100,000 population) were reported for this age group in the period studied (1989-2003), with a slight male predominance (28 deaths or 0.49 per 100,000 population).

Age 5-34 years: 805 deaths were registered during this period (1.51 per 100,000 population), with female predominance (1.75 per 100,000 population).

Age $\geq \mathbf{3 5}$ years: This age group accounted for $86.1 \%$ of asthmarelated deaths (4,264 total; 16.27 per 100,000 population), with a female predominance (18.46 per 100,000 population).

Years of potential life lost (YPLL): The average YPLL rate in the period studied was 71.5 per 100,000 population. Women were more affected than men ( 86.5 per 100,000 women compared to 56.7 per 100,000 men). It is noteworthy that in 1997, overall average YPLL began a decline, reaching 53.1 per 100,000 population that year and 43.0 per 100,000 population by 2003 .

Asthma mortality by months and seasons of the year The largest number of deaths $(61 \%)$ occurred during the Cuban dry season, November-April (mean temperature $22^{\circ} \mathrm{C}$ ).

\section{Asthma mortality risk}

By municipality: Asthma mortality risk ranked high in 73 of the country's 169 municipalities (43.2\%), distributed across the provinces of Pinar del Río (3), Havana (18), Havana City (15), Matanzas (3), Cienfuegos (4), Ciego de Ávila (8), Camagüey (8), Las

Tunas (7), Holguín (1), Santiago de Cuba (1), Guantánamo (4) and the Isle of Youth (1) (Fig. 2).

By meteorological variables: The meteorological variables found to have the highest correlation to asthma mortality and to determine greater risk were: atmospheric pressure (997.7-1024.3 $\mathrm{hPa} ; \mathrm{r}=-0.680)$, temperature $\left(21.3-24.3^{\circ} \mathrm{C} ; \mathrm{r}=-0.273\right)$, number of rainy days during the dry season (15.5-45.2 days; $r=-0.236$ ) and cloudiness $(2.99-5.51 \% ; r=+0.306)$, which determined a well-defined spatial pattern in western (Havana City and Havana Province) and central-eastern (Camagüey, Las Tunas and Holguín) Cuba (Fig. 3).

\section{DISCUSSION}

\section{Asthma mortality behavior, trends and prediction}

Global trends in asthma mortality varied throughout the 20th century. During the first half of the century, mortality rates remained relatively stable. In the $80 \mathrm{~s}$, a gradual increase in mortality was observed in several countries (England, Wales, France, Italy, United States and Argentina). By the end of the 80s and in the 90 s, mortality rates stabilized and gradually declined in certain countries (Australia, Canada, Germany, England, Wales, Finland, Argentina and Uruguay).[1,13,32-34] The behavior of asthma mortality in Cuba has not differed much from the rest of the world. The decline observed since 1997 resulted from a revision and correction of death certificates. Later declines can be attributed to specific health interventions, such as the creation of urgent care services in all Cuban municipalities, a national ambulance system equipped to provide treatment and reanimation, and special training for medical and paramedical personnel.[35] The asthma mortality rate has continued to decline to about 2 per 100,000 population with low rates predicted for the future, according to estimates based on 15-year mortality data. Efforts must be made, however, to continue reducing pre-hospital mortality.[36]

\section{Asthma mortality by age group and sex}

Analysis of the mortality rate in the 5-34 age group is the most important consideration in an epidemiological study on asthma.[37] This is the most specific group for evaluating mortality, as chances for identification and diagnostic coding errors are lower when compared to younger age groups (misdiagnosis and/or masking of the diagnosis with other illnesses that cause wheezing in 
young children, such as bronchiolitis) or to older people, who may have additional conditions, such as cardiovascular diseases that cause respiratory symptoms resembling those of asthma. In their research, Sears and Comino concluded that although the number of deaths in this age group was low compared to the prevalence of the disease, diagnostic certainty based on death certificates was above $90 \% .[33,34]$ Some articles have stated that rates for the population aged 5-34 generally range between 0.5 and 2.0 per 100,000 population[33,37-39] with a female predominance,[40] and this data coincides with our results.

The greater use of inhaled corticoids has helped reduce mortality and may explain the new trend in declining mortality rates.[39] In Cuba, in the early 1990s, Varona and Bonet identified low educational level, underestimation of the dangers of asthma, asthma attack in the preceding 15 days, and overuse of bronchodilator spray (8 times a day or more) as the primary factors associated with mortality (Varona P, Bonet M. Factores asociados a la mortalidad por asma en Cuba, 1991-1992; unpublished data). More recent studies in Cuba have found other factors associated with pediatric mortality, such as lack of knowledge about the disease among patients and their relatives, emotional factors (fear and anxiety), and low use of inhaled steroids (such as beclomethasone), which contribute to patients' vulnerability.[35,41,42] These factors have also been found in studies conducted in other parts of the world.[43,44]

The mortality rate for the population aged $>35$ years - including the elderly ( $\geq 60$ years) - was found to be higher than in the 5-34 age group. Several international publications[14,29] have proposed that asthma among the elderly is usually associated with other diseases of aging and is therefore frequently underdiagnosed and inadequately treated, particularly in terms of insufficient use of anti-inflammatory drugs, which may explain the higher mortality among this group. Consequently, it should be emphasized that establishing asthma as the cause of death among this group is the least reliable data from an epidemiological standpoint. Moreover, asthma may be confused with other cardio-respiratory diseases, and this data may artificially raise mortality rates. [6] Increased asthma mortality in this age group in Cuba has not been studied in depth, but we have found that this has occurred in other parts of the world in recent years. $[14,43]$

\section{Years of potential life lost (YPLL)}

The World Health Organization (WHO) estimates that asthma causes 15 million years of potential life lost (YPLL) globally per year and accounts for $1 \%$ of the total global burden of disease.[1] This indicator varies by geographic region (USA 0.9; Latin America and the Caribbean 1.1; Sub-Saharan Africa 0.6).[44] In Cuba, the negative impact of YPLL is consistently greater on women than on men; yet, Cuba ranks among the countries with low disability-adjusted YPLL, which may be explained by our consistent effort to diagnose, treat (81-95\% access to drugs), and monitor our population affected by asthma.[36]

\section{Months and seasons of highest asthma mortality}

Analysis of seasonal changes in asthma mortality is useful for developing prevention strategies. Some international studies have shown that asthma deaths and hospitalizations follow a seasonal trend, which varies by age group.[14] These studies have reported that mortality among young (5-44 years) asthmatic patients peaks during the summer months, whereas hospitalizations for the same group are highest in the winter.[14] These deaths could be interpreted as the result of reduced monitoring of patients, changes in their routines, and reduced access to medical care. A different pattern is observed in elderly persons, with higher rates for mortality and hospitalization during the winter months.[14]

During the period analyzed in this study, the majority of asthma deaths occurred during the Cuban dry season (November-April). These findings coincide with the results of studies conducted in countries with similar climatic conditions, such as Brazil,[16] South Africa,[45] and Japan.[46] Several authors have suggested a possible link between climate and a higher incidence of respiratory infections that can trigger potentially serious asthma attacks.[14,47,48] Approximately $60 \%$ of such attacks are thus found to have been preceded by a viral infection, most commonly a rhinovirus.[48]

Some authors also refer to high concentrations of environmental fungi (Alternaria, Cladosporium, Penicillium and Aspergillus, among others) in winter as a trigger. These fungi are potent allergens whose spores or other elements provoke allergic reactions, such as asthma, and are also found at unusually high levels (98\%) in the homes of asthmatic children and adults. $[49,50]$ The presence of these fungi, coupled with inadequate medication and delays in seeking emergency care,[41,42] aggravate the patient's condition, making a fatal outcome more likely.

We believe that another factor triggering asthmatic attacks during the winter months is precisely the direct effect of cold, dry air on the bronchial tree of an asthma patient during physical exertion, i.e., bronchoconstriction. Some studies have found this factor triggered attacks in up to $67.3 \%$ of asthmatic subjects.[51]

\section{Asthma mortality risk}

To our knowledge, asthma mortality in Cuba has not been analyzed using the smoothed standardized mortality ratio, which may explain differences in the interpretation and spatial geographic representation of the data. Several risk factors studied in the Cuban population (but not analyzed in this study) would indicate certain spatial geographic behavior patterns of asthma mortality, including psychological[42,52,54] and social factors, indoor air pollutants (tobacco smoke exposure with a $30 \%$ prevalence),[46,52] and outdoor air pollutants (hazardous levels of $-10 \mu \mathrm{m}$ suspended particulate matter with an annual mean of $\left.61.2 \mu \mathrm{g} / \mathrm{m}^{3}\right) \cdot[19,20,53]$

Data from the Commission for Environmental Cooperation (CEC), in association with the public health organizations and governments of Canada, the United States and Mexico, show increasing levels of childhood asthma throughout the region as a result of outdoor air pollution, such as low-level ozone and suspended particulates, which are an ongoing problem in the three countries.[55]

It should be remembered that climate changes are among the factors that trigger asthma attacks.[15-17,55,56] Studies done in Havana City found that, regardless of asthma type (intrinsic or extrinsic), an increase in asthma attacks was closely related to meteorological factors (weather-sensitive individuals).[5]

Judging from our results, aggravated asthma associated with higher risk of mortality exists in areas of Cuba with low mean 
effective temperature, low atmospheric pressure, cloudier skies, and more rainy days in the dry season (Havana Province, Havana City, Camagüey, Las Tunas and Holguín). Although the Isle of Youth is also considered a high-risk location, mortality there is likely conditioned by factors unrelated to climate, particularly frequency of steroid use, asthma therapy between attacks, education of asthma patients and their families, and quality of medical care; the latter two identified as risk factors for asthma outcomes in a 2007 study in Camagüey province.[57]

Our study in Cuba has corroborated the findings of various authors about the relationship between regional climate differences and increased rates of asthma mortality. $[8,17,55,58-60]$

\section{CONCLUSIONS}

Asthma mortality rates in Cuba are not alarmingly high and are expected to remain stable in coming years. Unfavorable meteorological variables in some geographic areas of the island may lead to fatal outcomes for some asthma patients but are not the only factors determining mortality from this disease. Preventive measures must be continued, particularly with asthmatic women, who suffer excess mortality from the disease. Improved follow-up of patients suffering acute asthma attacks and severe asthma is needed, given the high risk of death under unfavorable climatic conditions. Further study of other risk factors determining asthma mortality is recommended, as well as development of prevention strategies that take into account the seasonal nature of asthma mortality. 1 -

\section{REFERENCES}

1. Masoli M, Fabian D, Holt S, Beasley R. The global burden of asthma: executive summary of the GINA Dissemination Committee report. Allergy. 2004;59(5):469-78.

2. Martin LS, Cesar BS, Riva CP. Mortalidad por asma y EPOC en Argentina. MEDICINA Buenos Aires. 2001;61:513-21.

3. David ML, Polansky M. Patterns of Asthma Mortality in Philadelphia from 1969 to 1991. N Engl J Med. 1994;8(23):1542-46.

4. McFadden ER Jr, Edward LMD, Warren, MD. Observations on Asthma Mortality. N Engl J Med. 1997;127(2):142-47.

5. Guevara AV, León A, Ortiz PL, Seguí M. Variabilidad climática mensual y asma bronquial pediátrica en La Habana, Cuba. In: Memorias del IX Congresso Brasileiro de Meteorologia, Camps de Jordâo, 1996, p. 290-93.

6. Molina EE, Brown CLA, Prieto DV. Contaminación atmosférica y prevalencia de asma en Centro Habana. Rev Cubana Hig Epidemiol. 2001;39(1):5-15

7. Romero PM, Más-Bermejo P, Lacasaña NM, Téllez RSMM, Aguilar VJ, Romieu I. Contaminación atmosférica, asma bronquial e infecciones respiratorias agudas en menores de edad de La Habana. Salud Pública Méx. 2004;46:222-33.

8. Romero PM, Romieu I, Más P, Téllez S, Aguilar VJM. Contaminación Atmosférica, Crisis Aguda de Asma Bronquial e Infecciones Respiratorias Agudas en Menores de 14 años de la Ciudad de la Habana, Cuba. 9 de octubre de 2000. Available from: http://www.paho.org/Spanish/HDP/ HDR/RPG/CUBA-Res-1509.doc.

9. Osmanis A, Ferrer I, Llanes A, Suárez O, Quevedo N. Asma bronquial: algunos factores asociados a su grado de severidad. Archivo Médico de Camagüey. 2006;10(5).

10. Molina E, Brown L, Prieto V, Bonet M, Cuéllar L. Crisis de asma y enfermedades respiratorias agudas. Contaminantes atmosféricos y variables meteorológicas en Centro Habana. Rev Cubana Med Gen Integr. 2001;17(1).

11. Rodríguez de la Vega A, Tejeiro A, Robí A. Investigación sobre prevalencia nacional de asma bronquial en Cuba. Rev Cubana Adm Salud. 1983:9(Apr-Jun):95-118.

12. Instituto Nacional de Higiene, Epidemiología y Microbiología (INHEM). II Encuesta Nacional de Factores de Riesgo de Enfermedades Crónicas no Transmisibles en Cuba. Informe de Trabajo. La Habana: INHEM (CU); 2002.

13. Varona P. Encuesta Nacional de Asma y Enfermedades alérgicas en jóvenes. Informe Técnico. La Habana: Instituto Nacional de Higiene, Epidemiología y Microbiología (INHEM); 2005.
14. Baluga JC, Sueta A, Ceni M. Tendencia de la mortalidad por asma en Uruguay: 1984-2001. Relación con la venta de medicamentos antiasmáticos. Rev Med Uruguay. 2003;19:117-125.

15. Chi-Hung Chen AB, Sudha Xirasagar C, HerngChing L. Seasonality in Adult Asthma Admissions, Air Pollutant Levels, and Climate: A Populationbased Study. J Asthma. 2006;43(4):287-292.

16. Beringhs EM. Mortalidade por asma no município de São Paulo, Brasil: influência do clima. Revista de Saúde Pública. [online] [Cited: 16 Sept 2004]. Available from: www.siicsalud.com/des/ des041/04d27000.htm.

17. Ballester F. Air Pollution, Climate Change and Health. Rev Española Salud Pública. 2005;79(2):159-75.

18. Rodríguez $\vee$ et al. Estudio de la mortalidad por Asma Bronquial en Cuba. Rev Cubana Med. 1975;14(3):425-38

19. Fabré Ortiz D. Asthma mortality in Cuba during 1972-1993. Allergolet immunopathol. 1997;25(6):289-92.

20. Ministerio de Salud Pública (MINSAP). Anuario estadístico. La Habana: MINSAP; 1990

21. Ministerio de Salud Pública (MINSAP). Programa Nacional de Asma. La Habana: MINSAP; 2002.

22. Ministerio de Salud Pública (MINSAP). Anuario estadístico. La Habana: MINSAP; 2006.

23. Oficina Nacional de Estadísticas de Cuba. [online] [Updated: 2004; Cited: 16 Jan 2004] Available from: http://www.one.cu. Consulted:13 March 2004

24. Instituto Nacional de Meteorología de la República de Cuba, 2004. [online] [Updated: 2004; Cited: 3 Jan 2004]. Available from: http://www.met. inf.cu. Consulted: 13 March 2004

25. SAS, Statistical Software for Windows. Cary, North Carolina: SAS Institute Inc.; 1996.

26. Maplnfo Professional Version 6.5. Troy, New York: MapInfo Corporation.; 2001. Available from: http://ais.paho.org/sigepi/index.asp?xml=sigepi/ soporte.htm.

27. SigEPI 1.4, Sistema de Información Geográfica en Epidemiología y Salud Pública. Área de Análisis de Salud y Sistemas de Información de la Organización Panamericana de la Salud; 2005. Available from: http://ais.paho.org/sigepi/index. asp?xml=sigepi/soporte.htm.

28. ArcView GIS 3.3. Redlands, California: Environmental Systems Research Institute, Inc.; 2002.

29. Fernández NHM. Metodología para cartografiar la influencia de factores geoambientales en la distribución espacial de los índices de salud. Ciudad de la Habana, 2006. Cited in: Fernández Núñez HM. Tesis de Doctor en Ciencias Técnicas: Metodología para cartografiar la influencia de factores geoambientales en la distribución espacial de los índices de salud. Facultad de Geología. Instituto Superior Politécnico "José A Echeverría”. Ciudad de la Habana, 2006.

30. Rodríguez JG, Trémols AJ, Jiménez $A H$, González JR, Trujillo NF et al. Suelos 500000. Una Aplicación SIG para los servicios técnicos, la investigación y la docencia especializada. In: Memorias del Congreso Geomática 2000. Santiago de Cuba, Cuba: p.110. Cited in: Fernández Núñez HM. Tesis de Doctor en Ciencias Técnicas: Metodología para cartografiar la influencia de factores geoambientales en la distribución espacial de los índices de salud. Facultad de Geología. Instituto Superior Politécnico "José A Echeverría". Ciudad de la Habana, 2006.

31. López Pardo CM. La medición del estado de salud de la población y su relación con los determinantes. Rev Cubana Salud Pública. 2007;33(1).

32. Hills E. Accuracy of death certificates in bronchial asthma. Accuracy of certification procedures during the confidential inquiry by the British Thoracic Association, a subcommittee of the BTA Research Committee. Thorax. 1984;39:505-59.

33. Sears MR. Accuracy of certification of death due to asthma. A national study. Am J Epidemiol. 1986;194:1004-11.

34. Comino EJ. What explains falling asthma mortality? MJA. 2004;180 (11):595.

35. Rodríguez AA, Brugueras MC. Comportamiento del asma bronquial en Cuba e importancia de la prevención de las enfermedades alérgicas en infantes. Rev Cubana Med Gen Integr. 2006;22(1).

36. Ministerio de Salud Pública. Asma Bronquial. Programa Nacional de Salud [Monografía en Internet] [Citado: 14 de abril de 2005] Available from: http:// aps.sld.cu/bvs/materiales/programa/asma/introduccion.pdf

37. Buck $C$ et al. El Desafío de la Epidemiología. Problemas y Lecturas Seleccionadas. OPS/Washington. Publicación Científica No. 505,1988.

38. Sears MR. Worldwide trends in asthma mortality. Bull Int Union Tuberc Lung Dis. 1991; 66:79-83.

39. Suissa S, Ernst P, Benayoun S, Baltzan M, Cai B. Lowdose inhaled corticoisteroids and the prevention of death from asthma. $\mathrm{N}$ Engl $\mathrm{J}$ Med. 2000;343(5):332-6.

40. Archivo Venezolano de Puericultura y Pediatría. 2003;66(Suplemento 1):5.

41. Fabré D, Andina R, Parra M, et al. Programa educativo en niños y adolescentes asmáticos y sus padres. Rev Alergia Méx. 2004;51(1):2-8.

42. Fabré Ortiz D, Caraballo PM, González SS, Cabezas GMJ, Arjona RR, Coutin MG, et al. Factores psicológicos que contribuyen al asma en ni- 
ños y adolescentes asmáticos y sus padres. Rev Alergia Méx. 2005;52(4):161-70.

43. Sin DD, Tu JV. Underuse of inhaled steroids in elderly patients with asthma. Chest. 2001;119:720-5

44. World Bank. World Development Report 1993 Investing in Health. Oxford: Oxford University Press 1993

45. Zar HJ, Stickells D, Toerien A, Wilson D, Klein $\mathrm{M}$, Bateman ED. Changes in fatal and nearfatal asthma in an urban area of South Africa from 1980-1997. Eur Respir J. 2001; 18:33-37.

46. Nakazawa T, Dobashi K. Current asthma deaths among adults in Japan. Allergology Int. 2004;53:205-209.

47. Szot MJ. Mortalidad por enfermedades respiratorias en Chile durante 1999. Rev Chil Enferm Resp. [online]. 2003;19(1):8-14 [Cited 15 March 2007]. Available from: http://www.scielo.cl/scielo.php?script=sci_arttext\&pid=S0717$73482003000100002 \&$ Ing=es\&nrm=iso >

48. Boquete $M$, Carballada F. Alergia e infección. Alergol Inmunol Clin. 2000;15(2 Extraordinario):98112.

49. Denning D, O' Driscoll B, Hogaboam C. The link between fungi and severe asthma: a summary of the evidence. Eur Resp J. 2006;27(3):30.

50. Charles B, Chitra D, Mamta R, Jay P. Frequency of Fungi in Homes of Pediatric Allergy Patients. Allergy Clin Immunol Int J World Allergy Org, 2007;18(5):197-202.

51. Tafur LA, Victoria L, Saa Navia D. Características del asma bronquial en niños de Cali. Rev Colom Med. 1997;28(1):10-15.

52. Jiménez $F L$, Fernández $M L$, Sarmiento BG Comportamiento del asma bronquial en la edad pediátrica. Rev Cubana Med Gen Integr. 2001;17(1):43-49.
53. Bonet GM, Varona PP, Diez CP. Neuropatía epidémica cubana: algunos factores de riesgo en la población. Rev Cubana Med Trop. 2000; 52(2):126-132

54. Espinosa RA, Espinosa BA. Factores de riesgo asociados en los fumadores. Resultados de la Medición inicial del Proyecto Global de Cienfuegos. Rev Cubana Med. 2001;40(3):162-168

55. Comunicado de prensa conjunta OMS/CEC/4. Informe de indicadores sobre salud infantil y medio ambiente en América Del Norte: primicia mundial. 2006. [Cited: 12 Jan 2006] Available from: http://www.who.int/mediacentre/news/ releases/2006/pr04/es/index.html.

56. Verlato G, Calabrese R, De Marco R. Correlation between asthma and climate in the European Community Respiratory Health Survey. Arch Environ Health. 2002:57(1):48-52.

57. Toledo V, Herio J, FernándezA, Orlando P, Batule M, Vidaillet RJD, Escobar PJP. Asma bronquial y medio ambiente. Paper presented at Congreso de la Asociación Interamericana de Ingeniería Sanitaria y Ambiental; 1992 Nov 22-28, Havana, Cuba.

58. Baños Zamora M, Torres López D, Suárez Ramos L. Pacientes con alto riesgo en la urgencia por asma bronquial. 2007. [Cited: 25 Jan 2007] Available from: http://www.amc.sld.cu/amc/2007/ v11n2-2007/2196.pdf.

59. Cockburn S, Salinger J. Climate and Health. Does climate affect mortality in Auckland? Water \& Atmosphere. 2001;9(3)

60. Yung-Ling L, Ying-Chu L, Bing-Fang $\mathrm{H}$, Yueliang LG. Changing prevalence of asthma in Taiwanese adolescents: two surveys 6 years apart. Ped Allergy and Immunol. 2005;16(2):157-164.

\section{THE AUTHORS}

Silvia Josefina Venero Fernández (Corresponding Author: silviavf@inhem.sld. $\mathrm{cu}$, epidemiologist. Associate professor and researcher, Epidemiology and Public Health Division, National Institute of $\mathrm{Hy}$ giene, Epidemiology and Microbiology (INHEM), Havana, Cuba.

Francisco Javier González Barcala, specialist in pulmonary medicine, Santiago de Compostela Hospital, Spain.

Ramón Suárez Medina, Professor, Epidemiology and Public Health Division, National Institute of Hygiene, Epidemiology and Microbiology (INHEM), Havana, Cuba.

Dania Fabré Ortíz, allergist, Master of Science in epidemiology. Assistant professor of pediatrics, Juan Manuel Márquez Pediatric Teaching Hospital, Havana, Cuba.

Héctor Manuel Fernández Nuñez. Professor, José Antonio Echeverría Higher Polytechnic Institute, Havana, Cuba.

Received: November 19, 2007

Approved for publication: April 25, 2008

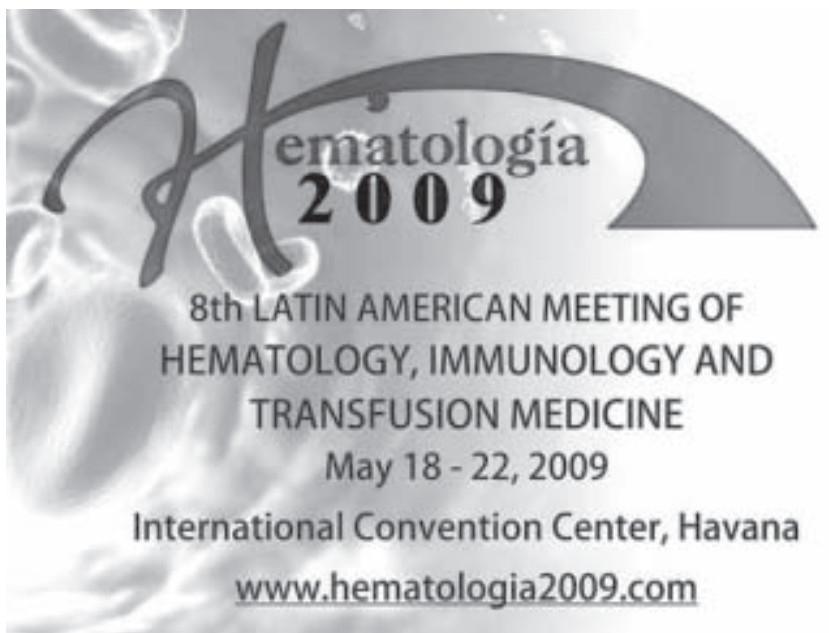

MEDICC Review, Summer 2008, Vol 10, No 3 $\ominus$ Stem cell transplantation

$\Theta$ Leukemiaśapd other malignant hemopathies

$\ominus$ Hemophilias and coagulation disorders

$\Theta$ Inherited and acquired anemias

$\Theta$ Immunodeficiencies and other immunological disorders

$\ominus$ Transfusion medicine and blood bank organization

$\ominus$ Hemovigilance

$\Theta$ Regenerative medicine applied to non-hematological diseases 